Niniejsza publikacja jest dostępna na licencji Creative Commons. Uznanie autorstwa-Użycie niekomercyjne-Bez utworów zależnych 3.0 Polska. Pewne prawa zastrzeżone na rzecz autora. Zezwala się na wykorzystanie publikacji zgodnie z licencja - pod warunkiem zachowania niniejszej informacji licencyjnej oraz wskazania autora jako właściciela praw do tekstu. Treść licencji jest dostępna na stronie: http://creativecommons.org/licenses/by-nc-nd/3.0/pl/

Lingwistyka Stosowana 24: 4/ 2017, 45-56

\author{
Izabela GAWLOWICZ
}

Uniwersytet Zielonogórski

\title{
Pojęcie „wspólnota międzynarodowa” w retoryce Międzynarodowego Trybunału Sprawiedliwości
}

\begin{abstract}
:
The Concept of „International Community” in the Rhetoric of the International Court of Justice. The subject of this article is the analysis of the chosen judgments of the International Court of Justice due to observe, how the Court uses this term. The Court's statement in the given scope makes an important part of international debate as to the analyzed concept. At the first glance the Court uses interchangeably the two terms: international society and international community, that are indeed synonymic. However the closer analysis shows, that the Court not only prefer the term "community", but also connects with it a lot of important factors, like members of this community, it's values and ideals. The review of some of the Court's judgments illustrates the spectrum of legal problems that might be connected with the concept of "international community" and the consequences of the uncertainty of this term.
\end{abstract}

\section{Wstęp}

Język prawniczy powinien być jednoznaczny, komunikatywny i adekwatny do przekazywanych treści. Jest on podstawowym narzędziem pracy prawnika. Sformułowane w zdaniu pierwszym wymogi niezwykle trudno jest jednak spełnić łącznie (choćby dlatego, że np. precyzję języka zapewnia skomplikowana terminologia, która z kolei utrudnia komunikatywność). Język pełni wyjątkową rolę pośrednika między powinnościami, które wyraża, a zinstytucjonalizowanymi formami zachowań społecznych.

Funkcje orzecznicze sądów międzynarodowych polegają na zastosowaniu istniejących uznanych norm i zasad prawa międzynarodowego do faktycznych problemów podniesionych przez strony sporu prawnego. Z natury rzeczy jednak normy prawa międzynarodowego są często niekompletne - implementacja idei nakłonienia państw o odmiennych systemach prawnych, tradycjach i często interesach politycznych do przyjęcia konkretnych norm traktatowych rodzi czasem konieczność dopuszczenia do ogólnych, czy wręcz ogólnikowych sformułowań w umowach międzynarodowych. Nadto niektóre kwestie celowo są pozostawiane orzecznictwu czy zwyczajowi do dalszego wyjaśnienia. Dokonywanie zatem wykładni prawa przez sądy międzynarodowe może mieć charakter wręcz prawotwórczy - dzieje się tak zazwyczaj wtedy, gdy sąd musi wypełnić lukę prawną (H.L.A. Hart 1998: 364 i nast.). To z kolei prowadzi do 
tzw. sądowego rozwijania prawa międzynarodowego. Językowa niedookreśloność prawa międzynarodowego wynika z jego wieloznacznej terminologii, spotęgowanej jeszcze różnicami w wersjach językowych traktatów.

Istotnym aspektem funkcjonowania sądów międzynarodowych jest styl (sposób, metoda) ich orzekania. Poprzez styl orzekania rozumieć należy łącznie metody dowodzenia, dobór terminologii, metody argumentacji, jak również strukturę wyroku. Styl ten wywiera silny wpływ na to, w jaki sposób sądy międzynarodowe są postrzegane, jak oceniana jest ich działalność i w konsekwencji - jakim cieszą się autorytetem. Wraz z rozwojem sądów międzynarodowych podlega on zmianom. Może on być przyczyną tego, że wyrok jest (lub nie jest) przekonujący. Istotnym zatem faktorem oceny stylu orzekania sądu międzynarodowego jest jego perswazyjność. To z kolei musi skierować uwagę badacza na odbiorcę (obserwatora) orzeczenia - nie o jego strony, lecz właśnie odbiorcę w szerokim tego słowa znaczeniu, o społeczność, która obserwuje i ocenia działalność sądu. Personifikacja owego odbiorcy jest w zasadzie kwestią kluczową z punktu widzenia sądu, który swoim orzeczeniom chce zapewnić autorytet i powszechną akceptację. Interesujące z naukowego punktu widzenia jest zbadanie, czy i jak sąd sam odnosi się do swojej „publiczności” w swoich orzeczeniach.

Na pytanie o to, kto jest zbiorowym odbiorcą (obserwatorem, beneficjentem w szerokim i umownym tego słowa znaczeniu) orzeczeń Międzynarodowego Trybunału Sprawiedliwości, organu sądowego Organizacji Narodów Zjednoczonych (dalej jako MTS lub Trybunał) pierwszą odpowiedzią, pozornie łatwą, narzucającą się wręcz odruchowo jest - międzynarodowa społeczność/wspólnota. To do niej adresowane są rozważania Trybunału, w których wyjaśnia on przepisy konwencji międzynarodowych, wzajemne relacje między różnymi aktami prawa międzynarodowego, przywołuje i opisuje wartości, którym prawo międzynarodowe ma służyć. Dla stosunków (ich intensywności, jakości, podstaw i rozwoju) wewnątrz tej wspólnoty orzeczenia Trybunału maja kluczowe znaczenie.

Poniższe rozważania poświęcono zbadaniu, jaki wpływ miało dotychczasowe orzecznictwo Międzynarodowego Trybunału Sprawiedliwości, organu sądowego Organizacji Narodów Zjednoczonych na kształtowanie się i rozwój ważnego dla prawa, w tym dla prawa międzynarodowego pojęcia „wspólnota (społeczność) międzynarodowa". Ta abstrakcyjnie pojmowana zbiorowość, powiązana z określonymi zasadami postępowania w stosunkach międzynarodowych i wartościami, które ma chronić akceptowane przez nią prawo, nie została jak dotąd satysfakcjonująco zdefiniowana $\mathrm{w}$ aktach prawa międzynarodowego, ani w doktrynie.

W niniejszej analizie uwzględniono jedną opinię doradczą oraz wybrane (z oczywistych względów redakcyjnych) wyroki Międzynarodowego Trybunału Sprawiedliwości, w których posługiwał się on terminami „międzynarodowa społeczność” lub „międzynarodowa wspólnota”, niezależnie od tego, czy robił to w głównym nurcie swoich rozważań na temat sporu, który państwa oddały mu do rozstrzygnięcia, czy też były to rozważania całkowicie względem głównego problemu poboczne.

Poza samymi wyrokami, uwzględnione zostały również niektóre dołączane do wyroków opinie odrębne i zdania indywidualne sędziów Trybunału. Stanowią one 
kopalnię wiedzy tak o istocie konkretnego sporu, jak i o racjach Trybunału w odniesieniu do poszczególnych instytucji prawa międzynarodowego. Zgodnie z art. 57 Statutu Trybunału (Dz. U. 1947, nr 23, poz. 90) Sędziowie Międzynarodowego Trybunału Sprawiedliwości mogą zaznaczyć, iż różnią się od większości co do sposobu rozumowania oraz konstruowania wniosków na jeden z dwóch sposobów: poprzez dołączenie do wyroku opinii odrębnej, która oznacza sprzeciw sędziego wobec sentencji wyroku (dissenting opinion), bądź zdania indywidualnego, w którym sędzia co do zasady akceptując treść orzeczenia, akcentuje swoją niezgodę na uzasadnienie wyroku (separate opinion) (R.Y. Jennings 1995: 498-499, A. Kozłowski 2009: 33). Opinie odrębne oraz zdania indywidualne, w zestawieniu z wyrokami MTS stanowią wielowymiarową ilustrację sposobu posługiwania się przez Trybunał kluczowym dla niniejszych rozważań pojęciem.

Do przeprowadzenia niniejszej analizy wybrano termin, który ma szczególne znaczenie we współczesnym prawie międzynarodowym publicznym i którym Międzynarodowy Trybunał Sprawiedliwości posługiwał się wielokrotnie i różnorodnie w swoich orzeczeniach oraz opiniach doradczych. Zrozumienie funkcji sądowej Międzynarodowego Trybunału Sprawiedliwości i jego szczególnej roli we współczesnym prawie międzynarodowym wymaga pełnego zrozumienia jego koncepcji i formowanych przez niego pojęć. Jednym z nich jest „wspólnota międzynarodowa”.

\section{1. „Wspólnota międzynarodowa” (international community - ang., communauté internationale - franc.) czy „międzynarodowa społeczność” (international so- ciety - ang., societe internationale - franc.)?}

Zarówno język prawa międzynarodowego, jak i język światowej polityki (w tym mediów) powszechnie $\mathrm{w}$ debatach o stosunkach międzynarodowych posługują się wyrażeniami „wspólnota międzynarodowa” oraz „społeczność międzynarodowa” jako niemalże słowami - kluczami, jako konstruktem myślowym personifikującym zbiorowość związaną wspólnymi wartościami, chroniącą je wspólnym prawem i dobrą wiarą. Dewaluacja języka polityki jednak powoduje, że wyrażenia te kojarzone są także pejoratywnie jako po prostu banały, nośne i puste hasła, słowa-wytrychy nie niosące ze sobą istotnych treści i nawiązań aksjologicznych.

Z leksykalnego punktu widzenia terminami tymi można posługiwać zamiennie, bo są one wobec siebie synonimiczne. Oba stosuje się na określenie zbiorowości ludzkich, zamieszkujących różne obszary świata, połączonych ze sobą więziami społecznymi i zainteresowanych ochroną pewnych uniwersalnych ludzkich wartości. W zbiorowościach tych powstają różnorodne więzi i relacje, w tym kształtowane są stosunki prawne.

Wyrażenia te jednak są również terminami języka prawnego i prawniczego, jakkolwiek akurat w doktrynie prawa międzynarodowego nie ma kompleksowych badań, które byłyby poświęcone rozróżnieniu tych pojęć. Są to pojęcia bez wątpienia dla prawa międzynarodowego szczególne, związane immanentnie z jego naturą, z podstawami światowego ładu, tożsamością członków tej społeczności. Tym większe znaczenie ma postawa, jaką wobec tych pojęć prezentuje Międzynarodowy Trybunał Sprawiedliwości i sposób, w jaki się nimi posługuje. 
Już prima facie można stwierdzić, że MTS używa wymienionych terminów dosyć często, swobodnie i co do zasady zamiennie, chociaż z niekwestionowaną przewagą dla „wspólnoty” nad „społecznością”; wydaje się również, że Trybunał robi to raczej intuicyjnie.

\section{1.}

W sprawie odszkodowań za szkody poniesione $w$ stużbie Narodów Zjednoczonych, opinia doradcza MTS z dnia 11 kwietnia 1949 r. ${ }^{1}$ spór dotyczył tego, czy Organizacja Narodów Zjednoczonych dysponuje prawnomiędzynarodową podmiotowością i czy, w konsekwencji, może objąć ochroną swoich funkcjonariuszy. Funkcjonariusz Narodów Zjednoczonych, obywatel Szwecji, hrabia Bernadotte został zabity w trakcie pełnienia swojej misji w Palestynie przez członków skrajnych ugrupowań izraelskich.

Celem wydania przez Międzynarodowy Trybunał Sprawiedliwości opinii doradczej, o przygotowanie której zwrócił się do MTS Sekretarz Generalny Organizacji Narodów Zjednoczonych z upoważnienia Zgromadzenia Ogólnego Organizacji, było m.in. ustalenie, czy Narody Zjednoczone jako międzynarodowa organizacja rządowa mają zdolność wystąpienia z roszczeniem przeciwko państwu odpowiedzialnemu za szkody wyrządzone Narodowym Zjednoczonym bądź ich funkcjonariuszom. W swojej opinii doradczej Trybunał skoncentrował się przede wszystkim na wyjaśnieniu istoty osobowości prawnomiędzynarodowej oraz prawnomiędzynarodowej podmiotowości. Ustalając, czy ONZ jako międzynarodowa organizacja rządowa ma zdolność do wnoszenia roszczeń przeciwko państwu, Trybunał zaznaczył, że podmioty prawa w systemach prawnych nie muszą być identyczne, bo ich natura jest pochodną potrzeb danej wspólnoty. W dalszej części swej opinii Trybunał posłużył się terminem „wspólnota międzynarodowa”, stwierdzając, że pięćdziesiąt państw, reprezentując zdecydowaną większość członków wspólnoty międzynarodowej miało prawo powołać do życia jednostkę, posiadającą obiektywną (w sensie uznaną przez nie wspólnie, a nie indywidualnie) osobowość międzynarodową, której składnikiem jest zdolność do wnoszenia roszczeń.

Opinię odrębną w tej sprawie złożył m.in. egipski sędzia Badawi Pasha², który kwestionował ustalenia Trybunału co do zakresu praw i obowiązków Organizacji. Sędzia Badawi w swojej opinii podkreślił, że dzięki rozwojowi międzynarodowych organizacji powstała w stosunkach międzynarodowych nowa jakościowo sytuacja, w której wspólnota międzynarodowa wymaga, by utworzona przez państwa organizacja mogła chronić swoich funkcjonariuszy, co jest konsekwencją powołania organizacji do życia.

W analizowanej opinii doradczej MTS terminem „wspólnota międzynarodowa” nie posługuje się ani często, ani szczególnie inspirująco, jednak sposób używania przez Trybunał tego terminu rodzi dwa wnioski. Trybunał z pewnością wlicza do wspólnoty międzynarodowej państwa świata (a nic w jego wywodach nie wskazuje na to, by wykluczał możliwość zaliczenia do niej także innych podmiotów) i tej

\footnotetext{
${ }^{1}$ (http://www.icj-cij.org/files/case-related/4/004-19490411-ADV-01-00-EN.pdf) (24.06. 2017).

2 (http://www.icj-cij.org/files/case-related/4/004-19490411-ADV-01-04-EN.pdf) (24.06. 2017).
} 
wspólnocie jako ciału zbiorowemu ze względu na jego naturę przypisuje pewne uprawnienia, wliczając $\mathrm{w}$ to prawo do tworzenia za wspólną zgodą państw ich zrzeszeń, które z kolei posiadają własne uprawnienia (nie będące jedynie sumą uprawnień państw członków takich związków).

Należy żałować, że nie dokonano w tej sprawie nawet pobieżnej analizy charakteru prawnego wspólnoty międzynarodowej jako zbiorowości, jej wewnętrznych powiązań i struktur, ani tego, co na ich formowanie wpływa. Wzmocniłoby to wymowę tej bardzo ważnej, bo uznającej podmiotowość międzynarodowej organizacji rządowej, opinii. Taka pogłębiona refleksja Trybunału na temat wspólnoty międzynarodowej mogłaby także stanowić przyczynek do rozwijania przez Trybunał koncepcji podmiotowości prawnomiędzynarodowej, przy uwzględnieniu zmian, jakie w świecie zachodzą od początków XX wieku.

\section{2.}

W sprawie Barcelona Traction, orzeczenie MTS z dnia 5 lutego 1970 r. ${ }^{3}$ spór między Belgią i Hiszpanią dotyczył kwestii ewentualnego sprawowania opieki dyplomatycznej nad osobą prawną. MTS w ciągu swojej kilkudziesięcioletniej działalności wydał kilka orzeczeń odnoszących się do tzw. opieki dyplomatycznej, jednej z najstarszych i najbardziej interesujących instytucji prawa międzynarodowego, zasadniczo uregulowanej międzynarodowym prawem zwyczajowym.

Opieka (ochrona) dyplomatyczna państwa nad (co do zasady) obywatelem - (ang. diplomatic protection) to opieka (ochrona) udzielana przez podmiot prawa międzynarodowego osobie fizycznej lub osobie prawnej wobec sprzecznego z międzynarodowym prawem publicznym działania innego podmiotu prawa międzynarodowego, wyrządzającego osobie fizycznej (lub prawnej) szkodę materialną bądź niematerialną. Podjęcie przez państwo A opieki (ochrony) dyplomatycznej nad swym obywatelem przekształca spór między osobą fizyczną, posiadającą obywatelstwo państwa A i państwem B (sprawcą szkody) w spór między państwami A i B. Spór taki może być skierowany do rozstrzygnięcia przez sąd międzynarodowy (lub organ arbitrażowy czy koncyliacyjny). Międzynarodowy organ rozstrzygający musi przede wszystkim ustalić, czy istnieją przesłanki do wykonywania opieki (ochrony) dyplomatycznej przez państwo występujące z roszczeniem (m.in. obywatelstwo/przynależność państwowa; sprzeczne z prawem międzynarodowym działanie państwa trzeciego).

Zasadniczo opieka dyplomatyczna przysługuje osobom fizycznym, ale w niektórych przypadkach i pod pewnymi warunkami może też być pełniona na rzecz osoby prawnej. Udziałowcami spółki kapitałowej Barcelona Traction, Light and Power Company, prowadzącej w Hiszpanii i Kanadzie działalność w sferze energetyki byli głównie (w blisko 90\%) Belgowie oraz belgijskie osoby prawne. Spółka prowadziła emisję obligacji nominowanych w funtach szterlingach, ale nie mogła już realizować swoich zobowiązań wobec wierzycieli w całości, m.in. dlatego, że władze hiszpańskie w pewnym momencie odmówiły zgody na transfer zagranicznych środków płatniczych. W efekcie kilku hiszpańskich wierzycieli spowodowało upadłość spółki.

\footnotetext{
${ }^{3}$ (http://www.icj-cij.org/docket/files/50/5387.pdf) (24.06. 2017).
} 
Belgia domagała się w postępowaniu przed Międzynarodowym Trybunałem Sprawiedliwości uznania, że działania władz hiszpańskich, arbitralne i podejmowane na szkodę belgijskich udziałowców spółki, naruszały prawo międzynarodowe oraz, że w związku Hiszpania ma obowiązek reparacji na rzecz Belgii.

Trybunał w tej sprawie wydał dwa wyroki: pierwszy na skutek wniesienia przez Hiszpanię zastrzeżeń wstępnych dotyczących jego jurysdykcji, drugi co do istoty sporu. W pierwszym wyroku Trybunał w ogóle nie użył terminu „,wspólnota międzynarodowa” (ani „międzynarodowa społeczność”), intrygująco posłużył się nim natomiast japoński sędzia Tanaka, który formułując swoją opinię odrębną ${ }^{4}$ wobec orzeczenia i odnosząc się do przepisów art. 36 ust. 5 statutu Trybunału stwierdził, że ich interpretacja musi uwzględniać ideały sprawiedliwości i pokoju, przeważające we wspólnocie międzynarodowej. Chiński sędzia V.K. Wellington Koo, który również złożył swoją opinię odrębną do tego orzeczenia ${ }^{5}$ wskazał, że dokonując oceny, czy państwo ma uprawnienie do tego, by objąć ochroną dyplomatyczną określoną osobę i wobec faktu, że instytucja ochrony dyplomatycznej ma charakter zwyczajowy oraz w braku powszechnie akceptowanych norm oceny kryteriów uzasadniających te ochronę, należy uwzględnić różnice w opiniach co do tej kwestii, szczególnie wobec szybkiego rozwoju inwestycji zagranicznych we wspólnocie międzynarodowej.

Trybunał ustalając, czy zobowiązania Hiszpanii, mają charakter erga omnes, podkreślił, że każde państwo, które przyjmuje na swoim terytorium podmioty zagraniczne (zagranicznych inwestorów, osoby fizyczne, czy prawne) zobowiązuje się objąć je swoją ochroną prawną, choć obowiązek ten nie ma charakteru bezwzględnego. W szczególności należy oddzielić zobowiązania państwa wobec wspólnoty międzynarodowej jako całości od tych, które państwo ma wobec innego państwa w zakresie sprawowania ochrony dyplomatycznej. Ponieważ zaś wielka jest waga praw, które wchodzą w grę w tym przypadku, wszystkie państwa mają (wspólny) interes prawny w ich ochronie i dlatego właśnie takie zobowiązania mają charakter erga omnes.

Do wspólnoty międzynarodowej i jej organów stanowiących prawo (ang. law making organs) odwołał się peruwiański sędzia Bustamante y Riverso ${ }^{6}$, który opatrzył wyrok w niniejszej sprawie zdaniem indywidualnym, podkreślając specyfikę działania holdingów poza terytorium państwa, z którym posiadają one więź prawną. W swoim zdaniu indywidualnym brytyjski sędzia Fitzmaurice ${ }^{7} z$ kolei posłużył się już nie konceptem wspólnoty międzynarodowej, ale odwołał do idei społeczeństwa poprzez zacytowanie klasycznej pracy L.R. Megarry i F. Baker'a, by podkreślić, że dla niezakłóconego funkcjonowania społeczeństwa niezbędne jest wypracowanie generalnych i abstrakcyjnych reguł postępowania, w tym zapewnienie zasady równości. Cytowany już wcześniej sędzia Tanaka w swoim zdaniu indywidualnym ${ }^{8}$ dołączonym do wyroku posłużył się wyrażeniem „wspólnota światowa” (ang. world community) podkreślając, że ważna dla instytucji ochrony dyplomatycznej zasada wyczerpania

${ }^{4}$ (http://www.icj-cij.org/files/case-related/50/050-19640724-JUD-01-06-EN.pdf) (24.06. 2017).
5 (http://www.icj-cij.org/files/case-related/50/050-19640724-JUD-01-05-EN.pdf) (24.06. 2017).
${ }^{6}$ (http://www.icj-cij.org/files/case-related/50/050-19700205-JUD-01-03-EN.pdf) (24.06. 2017).
$7{ }^{7}$ (http://www.icj-cij.org/files/case-related/50/050-19700205-JUD-01-04-EN.pdf) (24.06. 2017).
${ }^{8}$ (http://www.icj-cij.org/files/case-related/50/050-19700205-JUD-01-05-EN.pdf) (24.06. 2017). 
środków krajowych jest narzędziem zapewnienia równowagi między wymogami prawa krajowego i międzynarodowego w tej właśnie wspólnocie. Jeszcze innego sformułowania użył w swoim zdaniu indywidualnym amerykański sędzia Jessup ${ }^{9}$, mówiąc o regułach rządzących życiem „międzynarodowej wspólnoty biznesu” (ang. international business community). W tej samej opinii sędzia Jessup użył też wyrażenia „społeczność zarządzająca światem handlowym” pisząc o wpływie, jaki MTS wywiera na prawo międzynarodowe oraz o zasadach tego prawa odnoszących się do zagranicznych inwestycji. O strukturze wspólnoty międzynarodowej w perspektywie prawidłowego funkcjonowania międzynarodowego porządku prawnego pisze $\mathrm{w}$ swoim zdaniu indywidualnym włoski sędzia Morelli ${ }^{10}$, wskazując, że w takiej strukturze i w takim porządku prawa nie mogą przysługiwać jednostkom czy osobom prawnym, nie kwalifikowanym jako podmioty prawa międzynarodowego. Meksykański sędzia Padilla Nervo ${ }^{11}$ zaznacza, że uwzględniając potrzeby i dobro wspólnoty międzynarodowej we współczesnym zmieniającym się świecie, należy uznać, że są ważniejsze sprawy, niż interesy ekonomiczne i zyski, a uprawnione interesy natury moralnej i politycznej mogą być zagrożone działaniami nowoczesnych przedsiębiorstw. $\mathrm{W}$ relacjach między inwestorem, a państwem, w którym inwestycja jest realizowana powinna być zachowana właściwa równowaga dla dobra wspólnoty międzynarodowej oraz dlatego, by kapitał, który wędruje zagranicę dla zarobku, nie stanowił zagrożenia dla podstawowych wartości i godności państwa. Zdanie indywidualne do tego wyroku MTS dołączył także libański sędzia M. Ammoun ${ }^{12}$, który pisał o światowej wspólnocie narodów (ang. world community of nations) jako o społeczności, do której należą państwa - i te, które istnieją od wieków, i te, które niedawno uzyskały niepodległość, i którą rządzą zasady prawa i moralności. Wielokrotnie w swojej opinii sędzia Ammoun posługiwał się wyrażeniem „wspólnota narodów” oraz „międzynarodowa wspólnota" jako o społeczności nieprzypadkowo obejmującej co najmniej państwa, reprezentującej wspólne interesy i wartości i aspirującej do pewnego ideału równości i sprawiedliwości oraz podejmującej wysiłek roztoczenia nad swoimi członkami niezbędnej ochrony. Sędzia Ammoun powołuje się również na wspólne dziedzictwo ludzkości. Opinię odrębną do tego wyroku MTS dołączył sędzia M. Riphagen ${ }^{13}$, który stwierdził m.in., że międzynarodowe prawo zwyczajowe uznaje, w szczególności od czasu drugiej wojny światowej, poszanowanie podstawowych ludzkich wolności jako interes wspólnoty międzynarodowej. Sędzia M. Riphagen podkreślił także, że międzynarodowe prawo zwyczajowe odnoszące się do standardów traktowania cudzoziemców jest inspirowane wspólnym interesem międzynarodowej społeczności. Interesujące są uwagi tego sędziego odnoszące się do pojęcia międzynarodowego handlu, którego nie postrzega on jako strice ekonomicznej kategorii, ponieważ uznaje, że międzynarodowy handel i jego swoboda, podobnie jak podstawowe prawa i wolności ludzkie oraz jak respektowanie praw państw ze swej natury pozostają w interesie całej

${ }^{9}$ (http://www.icj-cij.org/files/case-related/50/050-19700205-JUD-01-06-EN.pdf) (24.06. 2017).

${ }^{10}$ (http://www.icj-cij.org/files/case-related/50/050-19700205-JUD-01-07-EN.pdf) (24.06. 2017).

${ }^{11}$ (http://www.icj-cij.org/files/case-related/50/050-19700205-JUD-01-08-EN.pdf) (24.06. 2017).

12 (http://www.icj-cij.org/files/case-related/50/050-19700205-JUD-01-10-EN.pdf) (24.06. 2017).

13 (http://www.icj-cij.org/files/case-related/50/050-19700205-JUD-01-11-EN.pdf) (24.06. 2017). 
międzynarodowej wspólnoty. Sędzia ten podkreślił naturalną odmienność praw i obowiązków wynikających z prawa krajowego od tych wynikających z prawa międzynarodowego, te drugie bowiem korespondują ze specyficznymi cechami i wymogami prawa międzynarodowego. Podkreślił także, że wymogi proceduralne w każdym systemie prawnym spełniają określoną i ważną rolę, ale ich nadmiernie rygorystyczne stosowanie nie jest właściwe dla prawa międzynarodowego jako prawa wspólnoty państw.

W sprawie Barcelona Traction Międzynarodowy Trybunał Sprawiedliwości jako ciało kolegialne oraz indywidualnymi głosami niektórych swoich sędziów wielokrotnie nawiązywał do pojęcia wspólnoty międzynarodowej, termin ten został też bezpośrednio wyrażony w opiniach odrębnych do obu wyroków i zdaniach indywidualnych sędziów. MTS nie podjął wprawdzie wysiłku zdefiniowania ani wspólnoty międzynarodowej (nawet poprzez np. wskazanie jej niezbędnych elementów), ani też owego interesu, na który sam Trybunał w tej sprawie zwracał uwagę, sposób jednak posługiwania się przez Trybunał tym pojęciem nasuwa kilka istotnych spostrzeżeń. Przede wszystkim wydaje się, że owa międzynarodowa wspólnota jest pojęciem, które Trybunał dość konsekwentnie personifikuje w określony sposób. Z wypowiedzi Trybunału i jego poszczególnych sędziów wynika, że zbiorowość, którą nazwa ta opisuje, prawdopodobnie ma bliżej nieokreśloną liczbę członków, do których z pewnością zaliczyć należy co najmniej państwa świata i organizacje międzynarodowe (ale być może także inne podmioty, Trybunał tego nie wykluczył), że rządzą nią zasady prawa międzynarodowego, które ma chronić istotne dla tej wspólnoty wartości, a jej członkowie posiadają wspólne ideały sprawiedliwości i pokoju. Ponadto jednym z celów tej wspólnoty jest ochrona jej członków.

\section{3.}

W sprawie personelu dyplomatycznego i konsularnego Stanów Zjednoczonych w Teheranie, orzeczenie MTS z dnia $24.05 .1980^{14}$, przedmiotem sporu między Stanami Zjednoczonymi i Islamską Republiką Iranu były ataki na ambasadę amerykańską w Teheranie, dokonane w lutym i listopadzie 1979 r., a także zajęcie ambasady i konsulatów amerykańskich w listopadzie 1979 r. i przetrzymywanie personelu dyplomatycznego i konsularnego USA oraz dwóch prywatnych osób jako zakładników przez rok w placówkach dyplomatycznych i konsularnych.

W swoim zarządzeniu o zastosowaniu środków tymczasowych z 15 grudnia 1979 $\mathrm{r}^{15}$. Trybunał wskazał, że zobowiązania ciążące na państwach, a wynikające z Konwencji Wiedeńskiej o Stosunkach Dyplomatycznych z dnia 18 kwietnia 1961 r. (Dz. U. 1965, nr 37, poz. 232) oraz Konwencji Wiedeńskiej o Stosunkach Konsularnych z dnia 24 kwietnia 1963 r. (Dz. U. 1982, nr 13, poz. 98) mają kardynalne znaczenie dla utrzymania dobrych stosunków między państwami w dzisiejszym świecie, tak pełnym współzależności. Nie ma bardziej fundamentalnego warunku utrzymywania stosun-

\footnotetext{
${ }^{14}$ (http://www.icj-cij.org/files/case-related/64/064-19800524-JUD-01-00-EN.pdf) (24.06. 2017).

${ }^{15}$ ICJ Reports 1979: 19.
} 
ków między państwami, niż zapewnienie nietykalności ambasad i przedstawicieli dyplomatycznych, stąd w całej historii narodów wszystkich wyznań i kultur obserwujemy wzajemne zobowiązania przyjęte dla realizacji tego celu. Instytucja dyplomacji jest wypróbowanym narzędziem efektywnej współpracy w międzynarodowej społeczności, które umożliwia państwom, niezależnie od różniących je systemów politycznych i społecznych, osiąganie wzajemnego zrozumienia oraz pokonywanie dzielących je różnic w sposób pokojowy. Odnosząc się w swym zarządzeniu do stanowiska irańskiego rządu z dnia 9 grudnia 1979 r., Trybunał stanowczo odrzucił możliwość traktowania takich działań, jak zajęcie ambasady i zatrzymanie osób korzystających z międzynarodowej ochrony jako spraw „marginalnych”, czy „drugorzędnych”, uwzględniwszy wagę zasad prawnych, które w tym przypadku muszą być brane pod uwagę oraz znaczenie, jakie społeczność międzynarodowa tym zasadom przypisuje. W swoim wyroku z dnia 24 maja $1980 \mathrm{r}$. w tej sprawie Trybunał uznał za swój obowiązek skierować uwagę całej międzynarodowej społeczności, której członkiem Iran był od niepamiętnych czasów na niepowetowane szkody, jakie mogą spowodować wydarzenia aktualnie rozważane przez Trybunał. Takie wydarzenia nie mogą być przyczyną unicestwienia całego kompleksu prawa, konstruowanego przez ludzkość od stuleci, utrzymanie którego ma kluczowe znaczenie dla bezpieczeństwa i dobrobytu skomplikowanej współczesnej międzynarodowej społeczności, dla której bardziej, niż kiedykolwiek istotne jest, aby zasady wypracowane dla zapewnienia uporządkowanego rozwoju stosunków były stale i skrupulatnie przestrzegane.

Zdanie indywidualne dołączył do wyroku w tej sprawie sędzia Manfred Lachs ${ }^{16}$, który sięgnął do takich wartości uniwersalnych, na których jest oparte prawo międzynarodowe i wszelkie dyplomatyczne metody układania relacji między podmiotami tego prawa - bez uznania pierwotnej roli tych wartości wobec przyjętych w międzynarodowej społeczności norm postępowania nie może być mowy o zapewnieniu bezpieczeństwa i pokoju. Sędzia Lachs przypomniał, że zasady i normy prawne kształtujące przywileje i immunitety dyplomatyczne - czego nigdy dość podkreślać - nie są wytworem jednej grupy narodów, z jednego kontynentu albo z jednego kręgu kulturowego, lecz były kształtowane przez wieki i respektowane przez narody wszystkich ras i cywilizacji. Wg polskiego sędziego decyzja Trybunału w tej sprawie stanowi nie tylko rozstrzygnięcie istniejącego sporu, ale przede wszystkim potwierdzenie, iż jednym z głównych filarów społeczności międzynarodowej jest pewien zespół norm prawnych, częściowo odzwierciedlonych w Konwencji Wiedeńskiej o stosunkach dyplomatycznych z dnia 18 kwietnia 1961 r., ale także wynikających z zasad ogólnych prawa międzynarodowego. Sędzia Lachs zwrócił uwagę na to, że na dzień 31 grudnia 1978 r. Konwencja Wiedeńska o stosunkach dyplomatycznych była przyjęta przez 132 państwa, włączając w to aż 61 z Afryki i Azji. W przypadku Konwencji Wiedeńskiej o stosunkach konsularnych z $1961 \mathrm{r}$. liczby przedstawiają się następująco: $\mathrm{w}$ tym samym czasie do konwencji tej przystąpiło 81 państw, w tym 45 z Afryki i Azji. Jest zatem oczywiste, że obie te konwencje odzwierciedlają prawo zaakceptowane przez wszystkie regiony świata oraz ludy z Północy i Południa, Wschodu i Zachodu. Prawo

${ }^{16}$ (http://www.icj-cij.org/files/case-related/64/064-19800524-JUD-01-01-EN.pdf) (24.06. 2017). 
to jest wspólną własnością międzynarodowej wspólnoty i zostało potwierdzone w interesie wszystkich narodów.

Wydaje się, że Międzynarodowy Trybunał Sprawiedliwości największą wagę do sposobu posługiwania się terminem „,wspólnota międzynarodowa” przykładał w sprawie personelu dyplomatycznego i konsularnego Stanów Zjednoczonych w Teheranie. Prawdopodobnie wynikało to ze specyfiki sprawy, w której naruszenie uświęconych i wielowiekowych norm postępowania w obszarze prawa dyplomatycznego stanowiło potężny cios w prawo międzynarodowe. To właśnie w tej sprawie Trybunał najwięcej uwagi poświęcił cechom tej wspólnoty, jej wartościom i znaczeniu we współczesnym świecie. Posługiwanie się terminem „wspólnota międzynarodowa” w tym orzeczeniu, choć pozbawione waloru definiowania, jest bardzo świadome i celowe, nienacechowane już przypadkowością i niewyłącznie intuicyjne.

\section{Wspólnota międzynarodowa w pracach B. Simmy}

Rozwijanie pojęcia międzynarodowej wspólnoty doktryna prawa międzynarodowego w dużej mierze zawdzięcza Bruno Simmie, niemieckiemu prawnikowi, który pełnił funkcje sędziego MTS w latach 2003-2012 i który w swoich pracach naukowych opisywał wiele problemów prawnych związanych z funkcjonowaniem MTS. Prace B. Simmy są szeroko znane doktrynie prawa międzynarodowego, ale jego poglądy są często uważane za kontrowersyjne Nie był wprawdzie pierwszym, który posłużył się tym terminem, jednak to właśnie on wypełnił go istotną z punktu widzenia prawa międzynarodowego treścią, badając i opisując - bardziej szczegółowo, niż czynił to sam Trybunał w swoich orzeczeniach - jego substancję normatywną. B. Simma założył, że prawo międzynarodowe jest i być powinno budowane wokół i ewoluujące $\mathrm{z}$ fundamentów, stanowiących statyczny system, skonstruowany z szeregu dwustronnych, egzekwowalnych stosunków prawnych opartych na porozumieniu między państwami (co właśnie B. Simma określa wprost jako „bilateralizm”) w kierunku formowania porządku prawnego wspólnoty międzynarodowej. Pojęcie „wspólnoty międzynarodowej" należy tu rozumieć dwojako: w znaczeniu konstruktu myślowego (czyli wieloznacznego zwrotu, którego znaczenie rozumiemy i stosujemy intuicyjnie, ale jest on często niepoprawnym synonimem terminu prawnego A. Chodu 2012: 10-11) klaryfikującego pewne wydarzenia na arenie międzynarodowej i w doktrynie prawa, a w międzynarodowych instytucjach jako formę wyrażenia normatywnego wyobrażenia o tym, czym prawo międzynarodowe być powinno. Jest to wspólnota międzynarodowa wszystkich osób fizycznych oraz zdolności prawa międzynarodowego do służenia interesom tej wspólnoty, co wzmacnia dążenia prawa międzynarodowego do uniwersalizmu. W jednym ze swoich wykładów B. Simma powiedział, że prawo międzynarodowe bez wątpienia osiągnęło taki poziom rozwoju, w którym nie realizuje się tylko we współzależnych prawach i obowiązkach między państwami, ale obejmuje wspólnotę międzynarodową jako całość, włączając w nią nie tylko państwa, ale także wszystkie istnienia ludzkie. Wg Simmy to wszystko sprawia, ze prawo międzynarodowe jest coraz bardziej publicznym, bo obrasta w elementy nie przystające do cywilistycznej, bilateralnej struktury tradycyjnego prawa. B. Simma porządek prawny wspólnoty międzynarodowej rozumie jako „bardziej świadomy społecznie porządek 
prawny", coraz bardziej odzwierciedlający właśnie interesy całej wspólnoty (interesy wspólne, dzielone), równolegle do partykularnych interesów państw. Używał także sformułowania „międzynarodowa wspólnota państw i ostatecznie całej ludzkości” (B. Simma/ A.L. Paulus 1998: 266-277).

\section{Wnioski}

Pojęcie „międzynarodowej wspólnoty”, zdecydowanie niejasne, zwłaszcza w zestawieniu z innymi synonimicznymi pojęciami, którymi Trybunał także (synonimicznie) się posługuje, już potencjalnie generuje pytanie o ewentualne skutki prawne tej niejasności. Rzeczywiście rozumienie przez Trybunał tego konceptu pozostaje głęboko ambiwalentne w orbicie międzynarodowej debaty prawnej. Wywołuje to pewne refleksje dotyczące znaczenia tego pojęcia nie tylko w perspektywie wpływu Trybunału na kształtowanie pewnych standardów postępowania w stosunkach międzynarodowych, co oczywiście pozostaje poza formalną siłą oddziaływania orzeczeń MTS, ale i poza pracami Trybunału. W powyższym, z konieczności nieco pobieżnym omówieniu wskazano w odniesieniu do konkretnych orzeczeń, jak Trybunał posługuje się terminem „międzynarodowa wspólnota”. Jest oczywiste, że brak w tym działaniu Trybunału konsekwencji, w jednych sprawach bowiem posługiwanie się tym terminem wydaje się intuicyjne $\mathrm{i}$ incydentalne, $\mathrm{w}$ innych Trybunał wyraźnie dzięki jego użyciu realizuje pewne cele w zakresie wyjaśniania obowiązującego prawa międzynarodowego. Mimo oczywistej konieczności zagłębienia się w rozważania dotyczące podmiotowości w prawie międzynarodowym i powiązania ich $\mathrm{z}$ analizowanym $\mathrm{w}$ niniejszych rozważaniach terminem, jego znaczeniem, konotacjami i konsekwencjami jego używania, Trybunał nie poszedł ta drogą, choć kilkakrotnie zbliżył się do tych zagadnień. Rozwój koncepcji międzynarodowej wspólnoty jest z pewnością dynamiczny i w pewnym sensie odbywa się także dzięki Trybunałowi. Jednak jego orzeczenia należy traktować raczej jako pewną ilustrację tego, jak wyrażenie to rozumieć, niż jako konstruktywne wskazówki na przyszłość.

\section{Bibliografia}

Chodu, A. (2012), Język na wokandzie: Ach te zapisy! (w:) „In Gremio” 5(78), 11-12. Hart, H.L.A. (1998), Pojęcie prawa. Warszawa.

Jennigns, R.Y. (1995), The United Nations at Fifty. The International Court of Justice after Fifty Years, (w:) ,American Journal of International Law” 89(3), 493-505.

Kozłowski, A. (2009), Międzynarodowy Trybunat Sprawiedliwości, (w:) J. Kolasa (red.), Współczesne sądownictwo międzynarodowe. Tom I - Zagadnienia instytucjonalne. Wrocław, 13-45.

\section{Akty prawne}

Statut Międzynarodowego Trybunału Sprawiedliwości z dnia 26 czerwca 1945 r., Dz. U. 1947, nr 23, poz. 90. 
Konwencja Wiedeńska o Stosunkach Dyplomatycznych z dnia 18 kwietnia 1961 r., Dz. U. 1965, nr 37, poz. 232.

Konwencja Wiedeńska o Stosunkach Konsularnych z dnia 24 kwietnia 1963 r., Dz. U. 1982, nr 13, poz. 98.

\section{Orzecznictwo}

Reparation for Injuries Suffered in the Service of the United Nations, Advisory Opinion 11.04.1949, ICJ Reports 1949. (URL http://www.icj-cij.org/files/case-related/4/004-19490411-ADV-01-00-EN.pdf). [Pobrano 24.06.2017].

Dissenting Opinion by Judge Badawi Pasha. (URL http://www.icj-cij.org/files/caserelated/4/004-19490411-ADV-01-04-EN.pdf). [Pobrano 24.06.2017].

Barcelona Traction. Light and Powers Company, Limited (Belgium v. Spain, Preliminary Objections), Judgment 24.06.1964. (URL http://www.icj-cij.org/files/caserelated/50/050-19640724-JUD-01-00-EN.pdf). [Pobrano 24.06.2017].

Dissenting Opinion by Judge Tanaka. (URL http://www.icj-cij.org/files/case-related/50/050-19640724-JUD-01-06-EN.pdf). [Pobrano 24.06.2017].

Dissenting Opinion by Judge Vellington Koo. (URL http://www.icj-cij.org/files/caserelated/50/050-19640724-JUD-01-05-EN.pdf). [Pobrano 24.06.2017].

Barcelona Traction. Light and Powers Company, Limited (Belgium v. Spain), Judgment 05.02.1970, ICJ Reports 1970. (URL http://www.icj-cij.org/files/case-related/50/050-19700205-JUD-01-00-EN.pdf). [Pobrano 24.06.2017].

Separate Opinion by Judge Bustamante. (URL http://www.icj-cij.org/files/case-related/50/050-19700205-JUD-01-03-EN.pdf). [Pobrano 24.06.2017].

Separate Opinion by Judge Fitzmaurice. (URL http://www.icj-cij.org/files/case-related/50/050-19700205-JUD-01-04-EN.pdf). [Pobrano 24.06.2017].

Separate Opinion by Judge Tanaka (URL http://www.icj-cij.org/files/case-related/50/050-19700205-JUD-01-05-EN.pdf). [Pobrano 24.06.2017].

Separate Opinion by Judge Jessup. (URL http://www.icj-cij.org/files/case-related/50/050-19700205-JUD-01-06-EN.pdf). [Pobrano 24.06.2017].

Separate Opinion by Judge Morelli (URL http://www.icj-cij.org/files/case-related/50/050-19700205-JUD-01-07-EN.pdf). [Pobrano 24.06.2017].

Separate Opinion by Judge Padilla - Nervo. (URL http://www.icj-cij.org/files/caserelated/50/050-19700205-JUD-01-08-EN.pdf). [Pobrano 24.06.2017].

Separate Opinion by Judge Ammoun. (URL http://www.icj-cij.org/files/case-related/50/050-19700205-JUD-01-10-EN.pdf). [Pobrano 24.06.2017].

Dissenting Opinion by Judge Riphagen. (URL http://www.icj-cij.org/files/case-related/50/050-19700205-JUD-01-11-EN.pdf). [Pobrano 24.06.2017].

Case Concerning United States Diplomatic and Consular Staff in Teheran (United States of America v. Iran), Judgment 24.05.1980, ICJ Reports 1980. (URL http://www.icj-cij.org/files/case-related/64/064-19800524-JUD-01-00-EN.pdf). [Pobrano 24.06.2017].

Dissenting Opinion by Judge Lachs. (URL http://www.icj-cij.org/files/case-related/64/064-19800524-JUD-01-01-EN.pdf). [Pobrano 24.06.2017]. 